\title{
NURTURING GREEN RETAILING: AN INSIGHT INTO INDIAN
}

\section{MARKET TRENDS}

\author{
Vinish $\mathbf{P}^{1}$, Maruthi Ram $\mathbf{R}^{2}$ \\ ${ }^{I}$ Associate Professor, Department of Management Studies, Global Academy of Technology \\ ${ }^{2}$ Professor and HOD, Department of Management Studies, Dayananda Sagar Academy of Technology \& Management
}

\begin{abstract}
Indian retailing industry has transformed over the years and shaped into organized format. The retailing industry accounts for 14 to 15 percent of country's GDP. Retailing is one of the most dynamic and fast paced industries in India and contributes around 8 percent of the employment. By 2018, the Indian retail sector is likely to grow at a CAGR of 13 per cent to reach US\$ 950 billion. Thus, the competition from within and outside has lead to survival of the fittest realizing the importance of following eco-friendly trends. Being the $5^{\text {th }}$ most preferred location for retailing in the world, Indian corporates had to give lot of importance to Global warming and its adverse effects on green cover. Going environmental friendly is quite challenging as redesigning the product and packaging is the cumbersome job. Also there are considerable efforts by organised retailers to develop green practices in store operations and through the entire supply chain. Large upfront investment and growing concerns of global retail giants entering Indian markets are matters of concern for domestic players. The transition from conventional store to an eco friendly one and building an eco friendly brand are definitely time consuming and calls for lot of brain storming. The transformation might lead to improving India's current stands, which is now at $133^{\text {rd }}$ in terms of carbon emissions. In addition, the modern channels of consumer education have made Indian consumers well aware of eco-friendly practices and ill effects of using non-recyclable products. The consumers are ready to spend more on organic and green products. Corporates have seen this as an opportunity to widen their market offerings. Also the industry has realized the importance of focusing on eco friendly products as part of corporate social responsibility in order to get a favourable attention from the general public and also to keep the other competitors out of race. Building approaches towards environmentally friendly process are of immediate relevance, not just for any manufacturing organisations, but also for the entire retailing industry. This paper attempts to gain a fair understanding about the initiatives and practices by the Indian retail sector towards green retailing.
\end{abstract}

Keywords: Retailing, Eco Friendly, Global Warming, Carbon

\section{INTRODUCTION}

Indian retail sector has undergone remarkable changes during the last decade making India, the fifth most attractive nation for retail investments in the world. According to 'Yes Bank-Assocham study', the retail market is expected to reach Rs.47 lakh crore by 2016-17 with a CAGR of 15 percent. Productivity in wide range of consumer goods and services were the major highlights of retailing in India. Even though in developed countries, the organsied retail commands $80 \%$ of the total retail trade, in India it's merely 8 to $10 \%$.Thus, there is lot of scope for market development in India. The driving factors behind the explosive growth of retailing in India are rising affluent group of consumers, increased urbanization, concept of nuclear families, and preference for branded products. The convenience of shopping multiple products under one roof and increased mall culture in metros are rising trends among the new generation. Indians liking for foreign culture combined with the modern life styles in cities give the retailing industry a boom over other industries. Also these factors are likely to support the growth of organsied retail in specific.

\section{Green Retailing}

Everyday millions of plastic bags are being carried by customers from various shopping outlets like supermarkets, apparel stores, Restaurants and Kirana shops. Consumers over the years have realized the difficulty in disposing and recycling of used products. Retailers, in order to gain competitive advantage over the rivals, have started highlighting social concerns as one of the prime objective in the marketing campaigns. Also, the consumers started recognizing the importance of buying products which can be disposed off easily and won't cause any harm to health. It has become important for retail managers to find innovative means of saving energy and reduce environmental pollution. In fact, sustainability has become a major part of overall retail strategy by the organisations.

Pricing remaining the key aspects of competition, Retail industry has majorly concentrated on discounts and offers. Indian market being highly price sensitive success of supermarkets and hypermarkets are of greater relevance. Achieving profitability in such price sensitive markets was majorly possible through reducing the operational cost. Green retailing also focus on reducing the operational costs and optimum utilization of available resources while reducing the environmental impacts. According to a study 
conducted by a global research firm, it was found that consumers in developing country are willing to pay marginally higher price of greener products which is a positive sign for the environment. Also this is a promising opportunity for the organized retailing industry. The retail organizations which are planning to start of their base in India should strive and develop green supply chains which should bring down the cost in the long run. Also a green infrastructure would help the organizations to bring down the operational cost and thus overall cost of manufacturing which would enable the companies to focus on low cost pricing strategy. Apart form enjoying the profits in the long run, the companies can build a green brand which could bring positive sentiments among the Indian consumers.

The Bureau of Energy Efficiency in India has identified the retail industry as an energy-intensive industry. The central government has stricter plans to curb the demand for energy by enforcing stricter laws on the Corporates making the self dependent on future requirements.

\section{REVIEW OF LITERATURE}

According to Mr. Ravi Singh, SG and CEO, WWF-India, the global retailing cover wide range of aspects like reducing energy consumption, green house gases, toxic waste and chemicals and innovation in the field of energy management. However, he has insisted on a sustainable supply chain in retailing in order to foster the industry.

According to Mr. Jamshyd Godrej, Trustee \& President Emeritus, WWF-India, the business goals should consist of profitability and environmental concerns which can go hand in hand. Also, he has stated that innovation is the key to retail success and through green strategy which should be as differentiation factor from its competitor.

According to Mr. Ravi Singh, Secretary General \& CEO, WWF India, the demand for food and fuel are sure ton increase in the future which means sustainable supply chain should be the foundation for any successful business and WWF India support such companies promoting green strategy.

According to Dr R. Pachauri, the ill-treatment of nature is likely to have some irreparable effects on human lives in terms of shortage of food, ecosystem and health. Hence it is necessary to balance the business objectives with environmental stability by proper waste management and customer education.

According to Smitu Malhotra, the time has come for green reatiling and organsied retailers in India will have to take the lead.

According to Namita Bhagat, most of the global retailers are striving to bring sustainability performance in retail operations to meet needy ecological concerns and social objectives as a part of Corporate Social Responsibility.
According to Ritu Sinha, consumer education and motivation is the key to development of green business in retailing in India. With increased awareness the consumers are opting for environmental friendly products.

According to Re-envisioning Retail, a new report on business and environment released by the Retail Council of Canada (RCC) in partnership with RBC Royal Bank an online article, Sustainability in retailing is no more just a aim but it has turned out to be a necessity in today's situation.

According to Sameer Barde, Assistant Secretary General, Retail, at the Federation of Indian Chambers of Commerce and Industry, there is an urgent need for retailers in India to think green but the concept is still blossoming in the country.

According to Arti Singh, senior vice-president, corporate affairs, Bharti Wal-Mart, the sustainability efforts in retailing in India are developed around three corporate goals namely renewable energy, zero waste, and sustainable products. Also the company is actively engaging suppliers, customers and government in this initiative.

According to Shubhra Saini, In India the dominant unorganised retailers don't prioritize environment sustainability factors, even though its is possible to reduce the cost by 20 to $25 \%$ by adapting green practices at their stores.

\section{NEED FOR THE STUDY}

Most Indians do shop at open markets consisting of large number of small shops called as kirana stores. Organsied retailing in India is still at nascent stage. The enormous growth potential of retailing in India has attracted both domestic and international players. With Global retailers adopting greener strategies and practices across the globe, it is essential for Indians to realize the importance of green business for a better future. With growing climatic and ecological changes affecting the agriculture and food industry, the cost of living has risen sharply over the years in India.. Human needs have grown boundless even though the resources have fallen shorter. Hence it is important for retailers to utilize their resources effectively by eliminating the waste and reduce energy consumption. Retailing being a prominent industry in India, contributing 14 to 15 percent of country's GDP, it is the right time to think, act and sell green in order to build better living conditions tomorrow Organisations can also gain benefits by going green. This study attempts to gain an insight of green retailing initiatives and significance for encouraging the 'green businesses' in our country.

\section{OBJECTIVES OF THE STUDY}

1. To understand the significance of fostering green retailing in India

2. To identify the initiatives towards green environment by organised retailers in India. 


\section{ANALYSIS OF THE STUDY}

\section{Indian Retail Market}

Retail industry in India basically constitute in two forms namely organized and unorganised. It is reported that there are over 13 million retail outlets operating currently in the country, where larger retail formats (larger than 500 sq. ft.) constitute merely $4 \%$. The growth of organsied retailing in India is measured at $35 \%$ per annum where as the unorganised sector is growing at 6 percent per annum. India has the highest number of retail outlets per person ( 7 per thousand).

Indian market has high intricacy in terms of wide geographic spread, poor infrastructure facilities and wide product choices by region which affects the overall profitability of the firm. Considering the rapid urbanization and growing population, it can be concluded that there are tremendous opportunities for growth of retailing in India.

\section{Necessity for Green Retailing in India}

Every retail organization intends to make more and more profits and attain 100\% market share. Industrialization has marked development of developing countries like India among the powerful developed countries. The environment was affected poorly by industrialization during 19th and 20th century. Nobody thought about ill effects of fast paced unplanned industrialization during those days. As the years progressed, aligning business practices in tune with the environment has become a non core activity in developed countries and then on to developing countries.

Even though India is 5th most preferred location for retailing in the world, $96 \%$ of the Indian market constitutes the twelve million plus unorganized outlets with average shop size less than 500 square feet. Also these kirana shops are run by small businessmen whose main objective are sheer profits and show no environmental concerns .Also their low literacy levels, primitive business practices, and unending cash crisis forces them to stick on to existing methods of selling. The organsied retailing growing at 14$18 \%$ percent per annum is likely to be the future market place for Indians. Hence the responsibility lies on the organsied retailers to lead the way and bring sustainable retailing practices.

Indian retail industry is currently not opened to Retail giants like TESCO, Carrefour and Wal-Mart because of the regulations from the government. As soon as the Government gives node to $100 \%$ FDI in multiband retailing, the Indian market will be dominated by foreign players who are cash rich. Also it would be easy for them to set up the business from scratch enforcing green strategies since changing them at a later date would cost them more.

\section{Efforts by Organised Retailers towards greener India}

A project named "Green Retailing in India" was kicked off on 4th February 2013. The project basically focuses on the Food and Bevergae sector which constitute about $60 \%$ retail turnover in India. The project was implemented in metros like Mumbai, Chennai, Delhi, and Bangalore due to impulsive growth of retailing in these cities. The objective of the project is to adopt sustainable thinking in retailing and approaches in their strategy, operations and marketing. Indian companies like Future Value Retail, Spencers Retail Ltd, Aditya Birla Retail Ltd, Smart Retail Pvt. Ltd. and Food world will steer the project. The project was partnered by the following:

- Confederation of Indian Industry's Centre of Excellence for Sustainable Development

- Retailers Association of India

- Collaborating Centre on Sustainable Consumption and Production

- Asia Society for Social Improvement and Sustainable Transformation (ASSIST)

- Austria Recycling (AREC)

- Sustainable Development Society (STENUM) Asia

Tesco planning to enter into Indian markets, has initiated the Carbon Disclosure Project (CDP) in 2007, for its climate change efforts has been making efforts to cut its carbon emissions. This is a motivation for domestic players in Indian markets since the competition in the future in beyond geographical boundaries and with dominant multi national corporations.

Tata Trent ltd has integrated economic progress, environmental concerns and social commitment into one theme.

RPG group has converted 20 plants into green facilities towards environment protection.Apart from this they have also invested in rain water harvesting system, paper waste recycling, e-waste collection etc.

Shoppers Stop commenced Eco Friendly Initiatives in 2007 with the mission to conserve energy and formulated "Energy Management Policy". The company is following 3Rs namely Reduce, Reuse and Recycle. The company recycles e-waste and clothes. They have invested in water conservation project and lowered operating expenses by reducing the power consumption in their stores. Shopper stop has also launched back to earth and exclusive e-brand that offer eco-friendly collection like recycled wood, recycled paper.

Uninor has become first telecom operator in India to introduce eco friendly retail signboards across retail outlets in major cities.

Global Brands like Woodland and Puma have already adopted eco-friendly initiatives by launching green initiatives. Wood land has launched Proplanet, which intend 
to achieve zero carbon emissions for its operations. The company also aims to become India's first carbon neutral chain. According to Harkirat Singh, MD, Woodland India, Woodland has already done a comprehensive carbon accounting for its stores in Karnataka and Delhi NCR region. Also the company is planning to encourage their customers who visit their stores to pledge their emission reduction for every solar water heater they use at their homes. Who ever ready to pledge, would be given an evoucher after they validate the claim and this is likely to share the carbon credits among customers of woodland. Puma on the other side has opened up its sustainable stores in Bangalore.teh store has followed sustainability through innovative design, mechanical and electrical installations, and material selections. Also the company's merchandise will be made from organic cotton and other products primarily sourced and produced in Africa using environmentally sustainable materials. Also its stores have introduced recycling program for footwear, apparel and soft accessories.

Nokia exclusive stores have set up Green boxes across their stores where the customers can deposit the used phones for recycling.

Mc Donald in India has redesigned their restaurant napkins, bangs which are basically made of recycled paper.

\section{Contribution of Other Key Players}

\section{Consumers}

Consumers of today are more concerned about environment and personal safety. Consumer medias have been successful in creating and commenting on various environmental issues that are linked with the lifestyle of today's generation. The increased awareness level has prompted the customers make right product and service choices. Consumers in large numbers have come forward to buy organic foods, jute bags over plastic bags, reusable containers, and energy efficient appliances.

\section{Government}

Government has take initiatives that will promote environmental friendly business through policy regulations and consumer awareness programs. By encouraging ban on production of plastic bags below 40 micron width and mandatory installation of solar water heaters on every new house constructed the ministry of environment shown active concern for the society's well being.

\section{Competitors}

Domestic and international competitors have begun adopting environmental friendly business practices which forced small and medium players follow the suit. Every retailer has insisted that they care for environment and have used environmental concern as a strategy for marketing their products and services. This in turn has lead to healthy competition among the various players in the industry. Green marketing and green supply chain were matters of significance as they have gained lot of attention during the past 2 to 3 years. The NGOs were actively involving themselves in creating and promoting awareness level campaigns among the general public

\section{Media}

Print, Visual and social media have been powerful in India contributing to the awareness of greener planet. Also they have successful in highlighting the threats likely to faced by the future generation and thus stopping today's generation from being non-eco friendly.

\section{CONCLUSION}

Environment changes are for sure .its upto to the generations to maintain the stability for a better future. It's the dusty of both business and consumers to ensure better living conditions for the generations to come. With the growing power of retailers it would be easy for them to influence their supply chain network and consumers to care for the environment. Collaborating with suppliers, adopting green practices at stores, reducing and redesigning the longer supply chains, it would be possible to bring a greener world. Green retailing has already assumed immense importance in the country .Media, NGOs and Government will have to play an active role in bring the situation into control and take appropriate actions at right time. The strategy need to be adopted at the earliest in countries like India as organsied retailing is still at budding stage. Also making appropriate policies now would save a lot of time, energy and money and contribute towards a greener planet.

\section{REFERENCES}

[1] Mr. Ravi Singh, SG and CEO, WWF-India, "Green Retail is the Need of the Hour", February 8,2013,WWF India available at http://www.wwfindia.org/?8580/Green-Retail-is-theNeed-of-the-Hour

[2] Mr. Jamshyd Godrej, Trustee \& President Emeritus, WWF-India, "Green Retail is the Need of the Hour", February 8,2013,WWF India available at http://www.wwfindia.org/?8580/Green-Retail-is-theNeed-of-the-Hour

[3] Mr. Ravi Singh, Secretary General \& CEO, WWF India, "Green Retail is the Need of the Hour", February 8,2013,WWF India available at http://www.wwfindia.org/?8580/Green-Retail-is-theNeed-of-the-Hour

[4] Smitu Malhotra, "Green Retailing", Business markets, April ,2012, available at http://bimtech.ac.in/wpcontent/uploads/2013/09/Green-Retailing

[5] Smitu Malhotra, "Time for green Retailing in India”, The Financial Express, May 6, 2013, available at http://archive.financialexpress.com/news/time-forgreen-retailing-in-india/1111824

[6] Namita Bhagat, " Green Route to Retail Success", Franchise India.com, September 20, 2012, available at http://www.franchiseindia.com/international/article/busi ness-insight/trends/Green-route-to-retail-success-9/

[7] Ritu Sinha, Green Retailing, "An Exploratory Study Examining the Effects of Sustainability on Global Retail Landscape Conference on Inclusive \& 
Sustainable Growth Role of Industry", International Journal of Academic conference proceedings, Volume No. 1, 2011, available at http://journal.ijacp.org/index.php/ISG/article/view/24

[8] Vidhi Choudhary, "Long road ahead for India's malls to go green", Live mint, April 12, 2012, online article available at http://www.livemint.com/Politics/5VBY2N7qNnNTSK EEo07MLN/Long-road-ahead-for-India8217s-malls-togo-green.html

[9] Shubhra "Futuristic green malls",Indiareatiling.com, September 18, 2014, available at http://www.indiaretailing.com/7/23/25/12129/Futuristic -green-malls 